International Journal of Social Sciences and Humanities
Available online at http://sciencescholar.us/journal/index.php/ijssh
Vol. 3 No. 3, December 2019, pages: $10 \sim 17$
e-ISSN: 2550-7001, p-ISSN: 2550-701X
https://doi.org/10.29332/ijssh.v3n3.339

\title{
Swadharma Grihastha Asrama on Educating Children toward Hindu Families
}

\begin{abstract}
CrossMark
Ni Made Arini a, Ida Ayu Gde Yadnyawati ${ }^{\mathrm{b}}$, Wayan Paramartha ${ }^{\mathrm{c}}$

Article history: Received 18 April 2019, Accepted: 31 August 2019, Published: 20 September 2019

\section{Correspondence Author ${ }^{\text {a }}$}

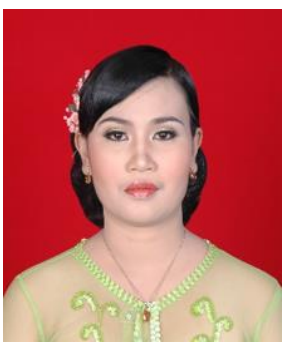

Abstract

The current article aimed at knowing and understanding swadharma grihastha asrama on educating children towards Hindu families. Data collection methods were observation, library studies, and in-depth interviewed. This research was conducted in Lombok Regency. The results of this study indicated that the teachings of Hinduism for Sarasamuscaya and Nitisastra have not been optimally implemented by Hindu parents in Lombok. It can be seen from economic factors, low awareness for the importance of education. Due to the parents were not able to meet the children material needs, for example, the fulfillment of nutrition, adequate places, and learning facilities, and the use of non-formal educational institutions, for example, course and tutoring subjects.
\end{abstract}

Keywords

course;

educating children;

grihasta dormitory;

swadharma;

tutoring;

e-ISSN: 2550-7001, p-ISSN: 2550-701X ๑ Copyright 2019. The Author. SS Journals Published by Universidad Técnica de Manabí. This is an open-access article under the CC BY-SA 4.0 license (https://creativecommons.org/licenses/by-sa/4.0/) All rights reserved.

\section{Contents}

Abstract 10

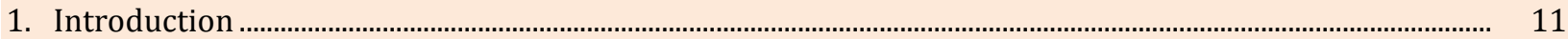

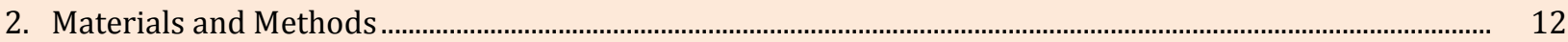

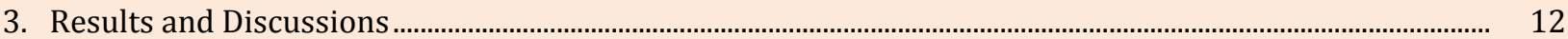

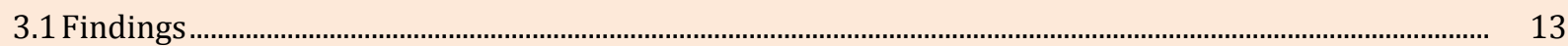

3.2 Suggestions

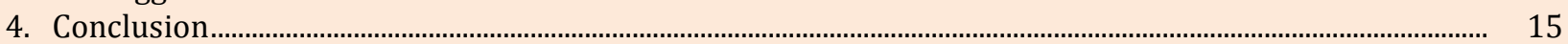

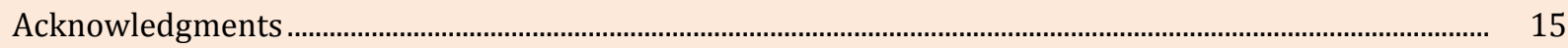

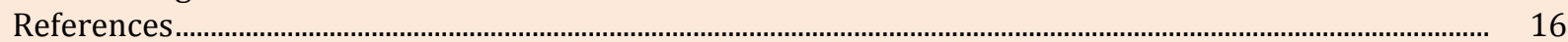

a STAHN Gde Pudja Mataram, Mataran, Indonesia

b Universitas Hindu Indonesia, Denpasar, Indonesia

c Universitas Hindu Indonesia, Denpasar, Indonesia 


\section{Introduction}

West Lombok is a regency in Lombok Island. There is one of the areas wherein the community has fairly high Hindu societies beside Mataram City. It is a regency has the same level of development as Mataram City. There is the location of the central government in NTB Province.

As there has an area fairly high level of development, West Lombok is a satellite city or a buffer city for Mataram City. It becomes an urban destination for migrants from various regencies in NTB. As a result, West Lombok is faced with various problems, for example, an increase in population, social problems, cultural shifts, intercultural conflicts, and other problems that cause the changes on the societies.

It is viewed as the negative effects of modernization and globalization. There is characterized by the rapid development of the world of tourism in West Lombok, involving the social and cultural life of their society. The consumptive lifestyles, individualistic attitudes, tourism life with the influence of westernized lifestyles, micro, causes families, especially parents, to have a side job or part job. It is hoped to be able to improve the family's financial and existence of society.

Santrock (2000), stated the disruption of various parental roles and the increasing demands of the role of family and substitute caregiver. It is due to the influence of modernization and globalization. There is a factor causing parents negligence in fulfilling their self-service to children proportionately. There is a tendency of parents who only focus on the physical fulfillment of children, only providing material needs, busy working and pursuing lifestyles, unconsciously neglecting the role and other swadharma towards children.

The phenomenon of parental negligence and the model of childcare in family life is also found in the results of a study of nuclear family dysfunction. The informal education of families of children is with special attention for the high schools on Mataram City. Arini et al., (2016), found the dominance of authoritarian parenting applied by parents. The family sample was used as the research object. The dominance authoritarian attitude of parents to children is reflected in how parents treat children with strict rules and sanctions, without giving children a chance to argue and communicate their development to their parents.

Arini et al., (2016), also mentioned that economic factors in the families majority with low middle-income economy as one of the main reasons for suboptimal fulfillment of parental obligations for their children. The economic factors and parent's lack of understanding how the importance of education, can be seen from the lack of parental support, especially, the aspects of non-formal education (tutoring, courses, training, and others). The lack of facilities is to support a learning atmosphere for children who are conducive at home. Likewise, how to meet their needs for recreation or family entertainment, as a medium to establish a sense of emotional closeness. Santosa (2015), stated that in interacting parents must pay attention to the most important relationship essence namely, the existence of mutual respect, mutual understanding, trust, and care for each other.

Santosa (2015), emphasized the good parent-child relationships contain the essence of mutual respect, with the aim of forming a sense of admiration for the quality regarding father or mother love to their children. Therefore, the word 'mutual' defines that parents must also present themselves as role models or real examples (parent modeling). As the parents said about their expecting to children.

The influence of modernization is sometimes also supported the culture existence. There is still based on society. It is less in favor of growth, development, and childcare patterns. Suyanto (2013), stated that there were still cultural practices to harm children, respecting physically and emotionally. Suyanto (2013), suggested childcare pattern still emphasizes child obedience to parents, applying physical punishment (whip, pecut, samblek) on children. The physical punishment is carried out by argument, to uphold the children's obedience value to parents.

The cultural practices are related to society negative habits. Arini (2015), expressed the social phenomena form on the society for example, several residents professions mastering in the North and South Karang Siluman environment, Cakranegara Subdistrict. It is based on some reasons and arguments. They are belonging to the lower economic community, choosing the profession as a seller of tuak (palm wine) or traders and keepers fighting chickens. This profession is considered normal. There are still exists due to the habit of consuming tuak from the surrounding society. Whereas, the services of raising or selling on fighting chickens,

Arini, N. M., Yadnyawati, I. A. G., \& Paramartha, W. (2019). Swadharma grihastha asrama on educating children toward Hindu families. International Journal of Social Sciences and Humanities, 3(3), 10-17. https://doi.org/10.29332/ijssh.v3n3.339 
historically from the existence of a people tradition who like tajen (to pit chickens) with the religious argument justification through the ritual implementation namely tabuh rah.

The similar habits have also been found in Gunungsari Subdistrict, particularly Taman Sari Village. There are still found tajen implementation. The perpetrators come from various areas around the village, even from outside the sub-district or district. The local society also indirectly contributes to the tajen implementation, for example, to be parking attendant, helping to manage the area or place for the tajen implementation, selling food around the area (mostly mothers), providing services in preparing fighting chickens.

The other form of negative habits for the social activities in Taman Sari Village is playing cards (remi, domino, ceki), unlike spending the time. A habit is also an activity carried out by housewives. As it is apart from other activities that must be undertaken by as housewives in Taman Sari Village, especially, in Dusun Rendang Bajur. The society generally still work as cultivators of fields and gardens. The mothers are to help gardening. They also have other activities, for example, trading and making handicrafts from palm leaf sticks to be ingke (knitted from stick-shaped plates).

Social acceptance or habit supports, professions, and traditions do not support the creation of an atmosphere conducive to child growth and development. As it is found in the middle society. There is an obstacle to achieving the goals of informal education in the family. Due to the repetition is seen and observed from the routine professional life of the parent by the child. They will be a strong stimulus in influencing the child. Through the imitation process, suggestion, and interactions identification with parents who are professionals of selling tuak and fighting chickens. They will be responded by the child in the form of psychological development and the child's personal character that do not expect. It stays away from what we expect of the characteristics and child attitudes become suputra (good children).

Various phenomena arise from the life of Hindu families in West Lombok Regency as a satellite city or supporting city of Mataram City, especially, the Hindu society in Dusun Rendang Bajur, Gunungsari Subdistrict, regarding the dynamics of informal education and childcare models in the family. It becomes the power of its own attraction to uncover further phenomena. This includes the traditions and customs that exist in the society, especially, the mothers are from Dusun Rendang Bajur which consists of three dusun (smaller are than a village) areas. The helplessness of formal education without supporting from family and society (informal), therefore, it cannot be maximal on forming character, morals, and fulfillment of knowledge for children. It is another trigger factor. To focus more on peeling and looking for the main root problems, there are from various children problems and adolescents belong in society. The present paper examined Swadharma Grihasta Asrama on educating children towards Hindu families in Dusun Rendang Bajur, Taman Sari Village, West Lombok Regency.

\section{Materials and Methods}

The study used a qualitative research approach on the type of phenomenological research to examine indepth about the parents swadharma phenomenon in parenting their children for Hindu families in Dusun Rendang Bajur. The phenomenology was used as a type of research because it is suitable for expressing an object convincingly. Even though, it is in the form of cognitive objects, actions, and speech (Soenyono, 2004). Various phenomena related to the implementation of parent's swadharma, especially, the fulfillment of informal education in the family can be clearly revealed. The current research aimed to explore and collect data through several stages, namely non-participant observation, in-depth interview, and library study.

\section{Results and Discussions}

The data collection and analysis has been conducted. It was obtained the following explanation. The role of swadharma grihastha asrama on educating children for Hindu families can be seen from the parenting patterns at Dusun Rendang Bajur in Taman Sari Village. The parents have been lack of understanding about ideal parenting is a major factor. The dominant parents apply authoritarian parenting and permissive parenting, produce negative child characters, for example, lacking independence and closeness, no have 
initiative or passivity and are not confident, aggressive, like to oppose and violate the norm. They want to win themselves, impulsive or unable controlling emotions, and labile.

Swadharma grihastha asrama on educating children according to Hinduism, those are in Sarasamuscaya and Nitisastra has not been optimally implemented. It can be seen from the family economic factors in Dusun Rendang Bajur and low awareness of the importance of education causes parents were not able to meet the children material needs for example, fulfillment of nutritional intake, adequate places and learning facilities, and the use of non-formal educational institutions, namely, tutoring subjects or courses. It is morally mentoring and attention is also the parent's motivation on the learning process and the cultivation of children's learning discipline at home. It is still not optimal. The religious education is still focused on aspects of ceremonies or rituals. There are not evenly distributed on aspects of ethics and tattwa. The positive learning model of religious teachings is also difficult due to the habits and parents profession who are less supportive, related to tuak, tajen, and card games unwittingly pose a psychological threat to children.

The parent's slokantara in Dusun Rendang Bajur generally still do not understand how to treat children in terms of age. They must know when to treat like a king, when to instill discipline and responsibilities, for example, servants and when like friends in the family. They are still acting as authoritarian as a child regulator or monitor. They are not as a friend who wants to hear the feelings and children's desire. It gives the child freedom, without good communication, and control. Ther could be negative responses from children in the form of rejection of everything on the rules form, prohibitions, and even advice from their parents.

The implications of swadharma grihastha asrama on educating children for Hindu families to child behavior. Firstly, the aspect of children's character education who are less independent and closed. They do not have the initiative or passive. They are not confident, having an impact on the low enthusiasm and internal children's motivation in completing education. There are from the elementary level to the top level, including at the tertiary level. Therefore, it has not been able to improve the self-quality, either through formal, nonformal, and informal education. The aggressive character like to oppose and violate the norm, willing to win alone, impulsive or unable to control emotions and unstable, affect the negative way of interacting with children at school, home or their environment. Likewise, having to follow and complete education, it will easily feel stressed, disappointed, emotional, and discouraged.

Secondly, on the socio-cultural aspect, the learning model of children's behavior is given by parents and their environment. It is the most powerful factor on influencing the children misinterpretation in Dusun Rendang Bajur societies about the habits and culture on it. It still regenerates itself in the mindset, character, and personality, as well as negative culture or habits. Thirdly, on the economic aspects of character formation and personality, the most children in Dusun Rendang Bajur are negative, affect of children's personal readiness when they are adults faced a very dynamic world of work, require high creativity, and innovation. The economic point of the viewed family due to the same rotation cycle remains on the middle-low economic level as experienced their parents.

\subsection{Findings}

Based on the data, the role of swadharma grihastha asrama on educating children, it can be found. Firstly, the most swadharma grihastha asrama society at Dusun Rendang Bajur in Taman Sari Village have not been fulfilled properly, due to economic factors and parent's way of thinking, parent's understanding is still low about ideal parenting is a major factor. Secondly, the dominant parents apply authoritarian parenting and permissive parenting, produce negative child characters, for example lacking independence and closeness. They do not have initiative or passivity. They are not confident, aggressive, like to oppose and violate the norm. They want to win alone, impulsive or unable to control emotions and unstable. Based on the data, swadharma grihastha asrama has not been fulfilled on educating children according to Hinduism. It is found.

1) Low awareness is for the importance of education. Due to parents are not able to meet the children material needs, for example, fulfilling nutrition, adequate place, and learning facilities, and the use of non-formal education institutions, for example, tutoring subjects or courses.

2) It is morally mentoring and attention, as well as, parent's motivation on the learning process and implanting of children's learning discipline at home is still not optimal.

3) The religious education is still focused on ceremonial aspects or ritual, not evenly distributed in the ethical and tattwa aspects.

Arini, N. M., Yadnyawati, I. A. G., \& Paramartha, W. (2019). Swadharma grihastha asrama on educating children toward Hindu families. International Journal of Social Sciences and Humanities, 3(3), 10-17.

https://doi.org/10.29332/ijssh.v3n3.339 
4) The positive learning model for religious teachings is also difficult. Due to the parent's habit and profession who are less supportive, related to drinking habits unlike tuak, tajen, and card games. They unwittingly become a psychological threat to children.

5) The parents still do not understand how to treat children in terms of age. There are belong when to treat like a king, when to instill discipline and responsibilities, for example, servants and when like friends in the family.

6) The parents are still authoritatively acting as child regulators or monitors. They are not as friends who want to hear feelings and the child's wishes. It gives the child freedom, without good communication, and control.

Based on the data, the implications of swadharma grihastha asrama on educating children for children's behavior. It can be found that.

1) The aspect of children's character education who are less independent and closed. They do not have initiative or passivity. They are not confident, impact on lacking enthusiasm and children's internal motivation in completing education. The elementary level to the top level, including at the tertiary level has not been able to improve the self-quality, either through formal, non-formal or informal education channels.

2) The aggressive character like to oppose and violate norms. They want to win themselves. They are impulsive or unable to control emotions and are unstable, affect the way of socializing with children negative either at school, home, or environment. Likewise, having to follow and complete education, it will easily feel stressed, disappointed, emotional, and discouraged.

3) The socio-cultural aspect of children's learning model behavior given parents and their environment is the most powerful factor on influencing the children's misinterpretation for Dusun Rendang Bajur societies about their habits and culture on it. It still regenerates itself on the mindset, character, and personality, as well as negative culture or habits.

4) The character's economic aspects on formation and personality most children in Dusun Rendang Bajur are negative. They are affected by the children's personal self-readiness. When they are adults faced the worked world is very dynamic, requires high creativity, and innovation.

\subsection{Suggestions}

The family and environment conditions Dusun Rendang Bajur societies require attention from various parties, for the government, public organizations, and education observers, especially, from educational institutions in tertiary institutions. The government through the BKKBN service and local government for Gunungsari Subdistrict and Taman Sari Village, in order to provide counseling and assistance on the hoping family program (PKH). In order to provide skills and training facilities for the societies, for example, PKBM-PKBM on various training programs.

The business fund assistance also needs to be provided by the government through the cooperative office. It is socialized through the directed and continuous development of MSMEs and cooperatives. In order to provide entrepreneurial stimulus to the community members, especially, the societies in Dusun Rendang Bajur.

The government through the Ministry of Religion of the Province of West Nusa Tenggara and West Lombok Regency together with religious counselors should provide more intensive and programmed counseling to the society. Mapping the region regarding the conditions and adherent's problems. Therefore, it can take preventive action, to prevent the conflict's emergence, internal and external to the public.

The private and state universities contribute knowledge and ideas, especially, concrete problem solving, through community service activities. There are programmed in the form of built areas and limited to a certain time. The community service activities are expected to be conducted in a directed and measurable and sustainable manner.

Higher education through lecturers and students is expected to conduct studies and scientific research. Those are in the form of thesis, thesis, dissertation, and programmed research. Researching and studying various phenomena of problems in society, thus, they can contribute ideas and solutions to problems that occur in society's lives. 


\section{Conclusion}

The role of swadharma grihastha asrama on educating children for Hindu families can be seen from the parenting patterns in Dusun Rendang Bajur, Taman Sari Village. They have not been able to be well implemented. The other than due to economic factors and parent's way of thinking, the lack of understanding about ideal care be the main factor. The dominant parents apply authoritarian parenting and permissive parenting, produce negative child characters, for example, lacking independence and closeness. They do not have initiative or passivity. They are not confident, aggressive, like to oppose and violate the norm. They want to win themselves. They are impulsive or unable controlling emotions and labile.

\section{Acknowledgments}

The authors would like to thank the editor of IJSSH for their valuable time, support and advice on finishing the present paper.

Arini, N. M., Yadnyawati, I. A. G., \& Paramartha, W. (2019). Swadharma grihastha asrama on educating children toward Hindu families. International Journal of Social Sciences and Humanities, 3(3), 10-17. 


\section{References}

Agra, I. B., Gelgel, I. P., \& Dharmika, I. B. (2018). Pressure on socio-cultural towards post-divorce Hindu women in Denpasar city. International Journal of Social Sciences and Humanities, 2(3), 63-78. https://doi.org/10.29332/ijssh.v2n3.191

Arini, F. D., Choiri, A. S., \& Sunardi, S. (2016). The Use of Comic As A Learning Aid To Improve Learning Interest of Slow Learner Student. European Journal of Special Education Research.

Arini, N. M. (2015). "Grahasta Asrama Sebagai Media Pendidikan Informal Pada Komunitas Hindu Kota Mataram”. Prosiding Seminar Hasil Penelitian Dosen STAHN Gde Pudja Mataram. Mataram : Pustaka Bangsa.

Arniati, I. A. K. (2018). Young Hindu generation behavior in Denpasar city. International Journal of Linguistics, Literature and Culture, 4(4), 76-85. https://doi.org/10.21744/ijllc.v4n4.269

Basrowi, M. (2004). Soenyono. 2004. Teori Sosial Dalam Tiga Paradigma.

Gepu, W., Suda, I. K., \& Suyasa, I. M. (2018). Religious conversion towards Hindu Kaharingan to Christianity. International Journal of Linguistics, Literature and Culture, 4(4), 25-37. https://doi.org/10.21744/ijllc.v4n4.257

Santosa, S., \& Jensen, M. D. (2015). The sexual dimorphism of lipid kinetics in humans. Frontiers in endocrinology, 6, 103. https://doi.org/10.1111/iwj.12096

Santrock, J. W. (2000). Psychology. International Edition.

Suara, I. D. M., Gelgel, I. P., \& Yasa, I. W. S. (2018). Pitra yadnya implementation for Hindu heroes. International Journal of Social Sciences and Humanities, 2(3), 136-148. https://doi.org/10.29332/ijssh.v2n3.223

Suarda, I. W., Yadnyawati, I. A. G., \& Suda, I. K. (2018). Portrait of Hindu religious teacher performance certified educator in junior high schools Denpasar. International Research Journal of Management, IT and Social Sciences, 5(3), 53-61.

Sukarma, I. W. (2016). Tri Hita Karana theoretical basic of moral Hindu. International Journal of Linguistics, Literature and Culture, 2(3), 102-116.

Suyanto, D. Bagong. 2013. Sosiologi Ekonomi, Kapi-talisme dan Konsumsi di Era Masyarakat Post-Modernisme. Surabaya: Prenada Media Groupa Cipta. 


\section{Biography of Authors}

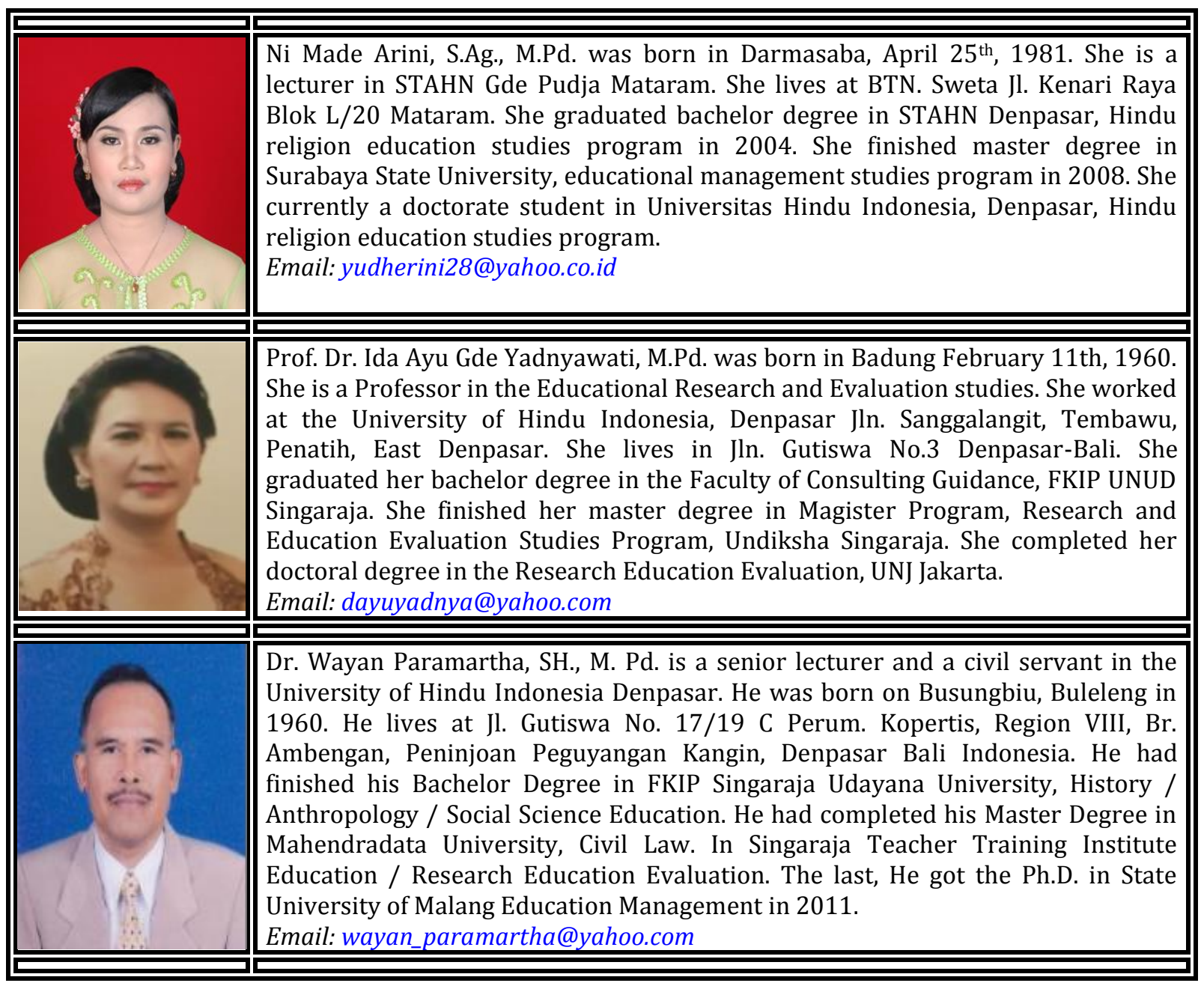

Arini, N. M., Yadnyawati, I. A. G., \& Paramartha, W. (2019). Swadharma grihastha asrama on educating children toward Hindu families. International Journal of Social Sciences and Humanities, 3(3), 10-17. https://doi.org/10.29332/ijssh.v3n3.339 